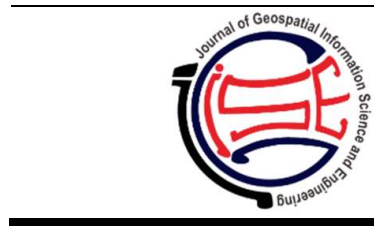

JGISE

Journal of Geospatial Information Science and Engineering

ISSN: 2623-1182 | https://jurnal.ugm.ac.id/jgise

\title{
Perubahan Nilai Tanah Zonasi Kawasan di Desa Kutuh Sejak Berkembangnya Obyek Daya Tarik Wisata Pantai Pandawa
}

\author{
The change Land Value of area zone in Kutuh Village Since the Development of Pandawa Beach Tourist \\ Attractions
}

\author{
I Gede Kurnia Nuharta, Antonius Karel Muktibowo², Syamsul Alam Paturusi² \\ ${ }^{1}$ Kementerian ATB/BPN, Program Studi PPMDK, Magister Teknik Arsitekstur - UNUD , Indonesia \\ 2 Program Studi PPMDK, Magister Teknik Arsitekstur - UNUD, Indonesia
}

Penulis Korespondensi: I Gede Kurnia Nuharta | Email: i.gknuharta@atrbpn.go.id

Diterima (Received): 08/10/2020 Direvisi (Revised): 17/10/2020 Diterima untuk Publikasi (Accepted): 23/10/2020

\begin{abstract}
ABSTRAK
Tanah sangat penting bagi kehidupan manusia karena tanah merupakan tempat utama dari semua kegiatan yang dilakukan oleh manusia. Sebagai sumber kesejateraan dan kemakmuran, tanah memiliki nilai berdasarkan kemampuannya secara ekonomis dalam hubungannya dengan produktifitas dan strategi ekonomisnya. Salah satu faktor yang mempengaruhi nilai tanah adalah faktor permintaan dan faktor penawaran sangat terkait dengan jumlah persediaan tanah dan kebutuhan tanah. Sejalan dengan itu perkembangan pariwisata akan membawa berbagai dampak perubahan. Salah satu dampak sosial ekonomi masyarakat dari perkembangan pariwisata diantaranya adalah perubahan nilai lahan. Berdasarkan latar belakang fenomena diatas sangat menarik untuk dikaji dampak perkembangan obyek daya tarik pariwisata Pantai Pandawa terhadap perubahan nilai tanah di Desa Kutuh. Adapun tujuan dari penelitian menganalisis perubahan nilai tanah zonasi kawasan yang hasilnya dapat digunakan sebagai pengetahuan pendukung dalam penataan ruang wilayah. Penelitian ini menggunakan metode penelitian kuantitatif dengan pendekatan spasial melalui teknik analisis spasial yaitu timpang susun (overlay) peta menggunakan Sistem Informasi Geografis (SIG) dan analisis statistik deskriptif untuk menganalisis perubahan nila tanah zonasi kawasan dan menyajikan hasil analisis dalam bentuk tabel dan grafik. Hasil dari penelitian terjadi perubahan nilai tanah di Desa Kutuh dengan peningkatan nilai tanah rata-rata zonasi kawasan sejak tahun 2012 sampai dengan 2018 pada zona pariwisata sebesar 7.08 \%; zona perdagangan jasa 10.65 \%; zona perkantoran $7.18 \%$; zona pertanian $5.02 \%$; zona perumahan $4.45 \%$; zona peruntukan lainya $4.95 \%$ dan zona sarana pelayanan umum $10.78 \%$. Berdasarkan hasil analsis perubahan nilai tanah rata-rata zonasi kawasan di Desa Kutuh diperoleh bahwa zonasi pelayanan umum yang berada dikawasan obyek daya tarik obyek wisata Pantai Pandawa memiliki peningkatan nilai tanah zonasi rata-rata kawasan tertinggi dengan demikian bahwa dampak perkembangan obyek daya tarik pariwisata Pantai Pandawa mengakibatkan naiknya nilai tanah di Desa Kutuh.
\end{abstract}

Kata Kunci: Nilai Tanah, Pariwisata, SIG

\section{ABSTRACT}

Land is very important for human life because land is the main place of all activities carried out by humans. As a source of welfare and prosperity, land has value based on its economic ability in relation to its productivity and economic strategy. One of the factors that influence the value of land is the factor of demand and supply which are closely related to the amount of land supply and land needs. In line with that, the development of tourism will bring various impacts of change. One of the socio-economic impacts of tourism development is the change in land values. Based on the background of the phenomenon above, it is very interesting to study how the impact of the development of the tourism object of Pandawa Beach on changes in land values in Kutuh Village. The purpose of this research is to analyze changes land value of area zone, the results of which can be used as supporting knowledge in spatial planning. This research uses quantitative research methods with a spatial approach through spatial analysis techniques, such as map overlay using Geographic Information Systems (GIS) and descriptive statistical analysis to analyze changes land value of area zone and present the results of the analysis in tables and graphs. The results of the study showed changes in land value of area zone in Kutuh Village with an increase in the average land value of the zoning area from 2012 to 2018 in the tourism zone by 7.08\%; service trade zone 10.65\%; office zone 7.18\%; agricultural zone $5.02 \%$; residential zone 4.45\%; other allotment zones $4.95 \%$; zone of public service facilities $10.78 \%$. Based on the results of the analysis of changes in the average land value of the zoning area in Kutuh Village, it is found that the zoning of public services in the area of the tourist attraction of Pandawa Beach has the highest average increase land value, so the impact of the development of the tourism object of Pandawa Beach resulting in an increase in the value of land in Kutuh Village. 


\section{Pendahuluan}

Lahan atau land dalam terminologi masyarakat Indonesia pada umumnya dikenal dengan tanah. Tanah sangat penting bagi kehidupan manusia karena tanah merupakan tempat utama dari semua kegiatan yang dilakukan oleh manusia. Selain itu, tanah berfungsi sebagai sumber kesejahteraan dan kemakmuran bagi pemiliknya ataupun mereka yang menguasai. Sebagai sumber kesejateraan dan kemakmuran tanah memiliki nilai berdasarkan kemampuannya secara ekonomis dalam hubungannya dengan produktifitas dan strategi ekonomisnya. Menurut Presylia (2002) dalam Sihombing, Subyinato \& Amarrohman (2018), nilai tanah dikelompokkan menjadi nilai tanah langsung dan nilai tanah tidak langsung, nilai tanah langsung merupakan suatu ukuran nilai kemampuan tanah yang secara langsung memberikan nilai produktifitas dan kemampuan ekonomisnya, sedangkan nilai tanah tidak langsung adalah suatu ukuran nilai kemampuan tanah dilihat dari segi letak strategis sehingga dapat memberikan nilai produktifitas dan kemampuan ekonomis.

Menurut Sutawijawa (2004), di dalam jurnal American Institute of Real Estate Appraisers (Wolcott, 1987: 22-63), mengemukakan faktor-faktor yang dapat mempengaruhi nilai tanah dan bangunan antara lain: Faktor ekonomi, ditunjukkan dengan hubungan permintaan dan penawaran Faktor sosial, ditunjukkan dengan karakteristik penduduk yang meliputi jumlah penduduk, jumlah keluarga, tingkat pendidikan, tingkat kejahatan dan lain-lain; Faktor pemerintah, seperti halnya berkaitan dengan ketentuan perundang-undangan dan kebijakan pemerintah bidang pengembangan atau penggunaan tanah (zoning). Selain itu, teori lokasi yang dikemukakan oleh Johan Heinrich Von Thunen dalam Widiarsa dan Suartika, (2018), menyatakan bahwa harga tanah ditentukan oleh jarak lokasi geografis lahan terhadap pusat kegiatan kota atau Central Business District (CBD), semakin dekat lokasi lahan terhadap CBD, maka semakin tinggi pula harga dan permintaan terhadap lahan tersebut, sebaliknya, semakin jauh lokasi tanah terhadap CBD, maka semakin rendah pula harga dan permintaan terhadap tanah tersebut. Selain itu konsolidasi tanah, yaitu proses penataan pertanahan, juga mampu meningkatkan nilai tanah (Astrisele dan Santosa, 2019).

Penelitian terkait perubahan nilai tanah yang dilakukan sebelumnya, antara lain Oksaping dkk (2019), Sutawijaya (2004), Tampubolon dkk (2016), Anugrah dkk (2017), AlVatia dan Nugroho (2019). Oksaping dkk (2019) melakukan penilaian tanah di wilayah Kabupaten Sukoharjo menggunakan metode AHP. Sutawijaya (2004) menganalisa faktor-faktor yang mempengaruhi nilai tanah sebagai dasar penilaian Nilai Jual Obyek Pajak (NJOP) PBB di kota Semarang, dengan hasil penelitiannya faktor kepadatan penduduk, jarak ke pusat kota, lebar jalan, kondisi jalan, ketersediaan sarana transportasi angkutan umum bus/angkot, dan yang terakhir adalah faktor lingkungan yang bebas banjir sangat berpengaruh terhadap nilai tanah di Kota Semarang. Tampubolon, dkk (2016), juga menganalisa perubahan nilai tanah akibat perpindahan bandara Polonia di kelurahan Anggrung, kota Medan dengan hasil penelitianya perpindahan bandara Polonia secara mendasar memberikan efek yang tertinggi dalam perubahan nilai tanah dan membawa efek positif bagi warga dalam kegiatan transaksi jual-beli tanah, investasi dan memanfaatkan tanah untuk kegiatan ekonomi lainnya di kelurahan Anggrung, Kecamatan Medan Polonia. Anugrah, dkk (2017) menganalisis perubahan nilai tanah akibat perubahan penggunaan tanah menggunakan SIG di pulau Karimunjawa dan pulau Kemojan yang hasilnya dari penelitian pengujian model prediksi harga tanah yang diperoleh pada penelitian ini masih belum memuaskan karena belum memasuki batas toleran yang ditetapkan sebagai syarat harga prediksi tahun berikutnya. Al-Vatia dan Nugroho (2019) dalam penelitian menganalisis pengaruh rencana penggunaan lahan pada Peta Rencana Pola Ruang dalam Rencana Detil Tata Ruang (RDTR) terhadap nilai tanah di Kecamatan Gamping, Sleman, D.I. Yogyakarta tahun 2013 s.d 2018 yang pada kesimpulanya dari hasil uji-t yang dilakukan terhadap masing-masing variabel bebas terutama pada varibel rencana penggunaan lahan diketahui bahwa variabel rencana penggunaan lahan berpengaruh terhadap nilai tanah walaupun hanya berpengaruh secara signifikan di tahun 2016, serta hasil evaluasi model diperoleh nilai Coefficient of Variation (COV) yang terbentuk belum cukup baik untuk memprediksi nilai tanah khususnya untuk memprediksi nilai tanah di wilayah penelitian.

Kabupaten Badung memiliki posisi strategis dengan adanya Bandara Internasional I Gusti Ngurah Rai sebagai pintu gerbang utama masuknya wisatawan mancanegara dan nusantara. Posisi strategis menjadikan Kabupaten Badung sebagai pusat pertumbuhan investasi di bidang pariwisata (Patera, 2016). Terutama di kawasan Badung selatan yang merupakan bagian dari ekosistem pesisir dan permukiman dengan dominasi kegiatan permukiman perkotaan, perdagangan, jasa dan kepariwisataan. Pantai Pandawa merupakan salah satu tempat wisata pantai yang berpasir putih yang sangat terkenal dan termasyur di dunia berada di Kabupaten Badung, Kecamatan Kuta Selatan, Desa Kutuh.

Berdasarkan data dari Kepala Penataan Pantai Pandawa, pada tahun 2013 jumlah kunjungan wisatawan nusantara mencapai 337.991 orang dan jumlah kunjungan wisatawan mancanegara mencapai 80.577 orang, sedangkan kunjungan wisatawan mancanegara pada tahun 2014 adalah sebesar 87.411 orang atau meningkat $8,4 \%$ dari 
tahun 2013 dan wisatawan nusantara sebesar 892.814 orang atau meningkat 164\% dari tahun 2013 (Bambar \& Anom, 2016). Sejalan dengan itu perkembangan pariwisata akan membawa berbagai dampak perubahan, salah satu dampak sosial ekonomi masyarakat dari perkembangan pariwisata diantaranya adalah perubahan nilai lahan (Ritchie \& Goeldner, 1987; Dipayana \& Sunarta, 2015). Keterbatasan ketersediaan tanah sebagai akibat dari jumlah permintaan tanah yang meningkat jauh lebih besar dari tanah yang dapat disediakan akan mendorong kenaikan nilai jual tanah (Astuti et al., 2015), yang pada akhirnya mampu meningkatkan pajak bumi dan bangunan (Aristalindara dkk, 2020). Untuk mendukung permintaan tanah yang tinggi diperlukan administrasi pertanahan yang baik (Aditya dkk, 2020).

Berdasarkan latar belakang fenomena di atas penelitian ini bermaksud untuk menganalisis rencana peruntukan zonasi kawasan dan perubahan nilai tanah zonasi kawasan sejak berkembangya obyek daya tarik pariwisata Pantai Pandawa di Desa Kutuh, Kecamatan Kuta Selatan. Adapun tujuan dari penelitian untuk menganalisis perubahan nilai tanah zonasi kawasan yang hasilnya dapat digunakan sebagai pengetahuan pendukung dalam penataan ruang wilayah khususnya bagi pemerintah kabupaten dalam rangka mewujudkan penataan ruang wilayah yang aman, nyaman, produktif, dan berkelanjutan.

\section{Data dan Metodologi}

\subsection{Data dan Lokasi}

Lokasi penelitian dilakukan di Desa Kutuh merupakan pemekaran dari Desa Ungasan yang telah diresmikan pada tahun 2002, dengan luas wilayah sebesar \pm 883.409 ha. Setelah menjadi Desa definitif, Desa Kutuh berusaha mandiri untuk memajukan Desa dengan mengandalkan potensi-potensi yang ada, salah satunya adalah Pantai Pandawa. Pantai Pandawa dahulu dikenal oleh masyarakat lokal dengan nama Pantai Melasti atau Pantai Kutuh, karena fungsi pantai saat itu hanya sebatas acara ritual melasti. Desa Kutuh merupakan salah satu Desa yang berada di wilayah Kecamatan Kuta Selatan dengan batasbatas wilayah sebelah utara berbatasan dengan Kelurahan Jimbaran, sebelah selatan berbatasan langsung dengan Samudera Hindia, sebelah barat berbatasan dengan Desa Ungasan dan sebelah timur berbatasan dengan Kelurahan Benoa.

Data-data yang digunakan pada penelitian ini adalah data sekunder yang diperoleh dari instansi terkait, antara lain:

1. Peta Rencana Pola Ruang Rencana Detil Tata Ruang (RDTR) Kecamatan Kuta Selatan, format shapefile (shp) yang diperoleh dari Dinas PUPR Pemerintah Kabupaten Badung.

2. Peta Administrasi Desa Kutuh, format shapefile (shp) yang diperoleh dari Kantor Pertanahan (BPN) Kabupaten Badung (Gambar 2.1).
3. Peta Zona Nilai Tanah (ZNT) Kabupaten Badung tahun 2012-2018 format shapefile (shp) yang diperoleh dari Kantor Pertanahan (BPN) Kabupaten Badung.

Masing-masing peta diatas sudah dalam sistem proyeksi peta TM-3 pada zona 50.1 .

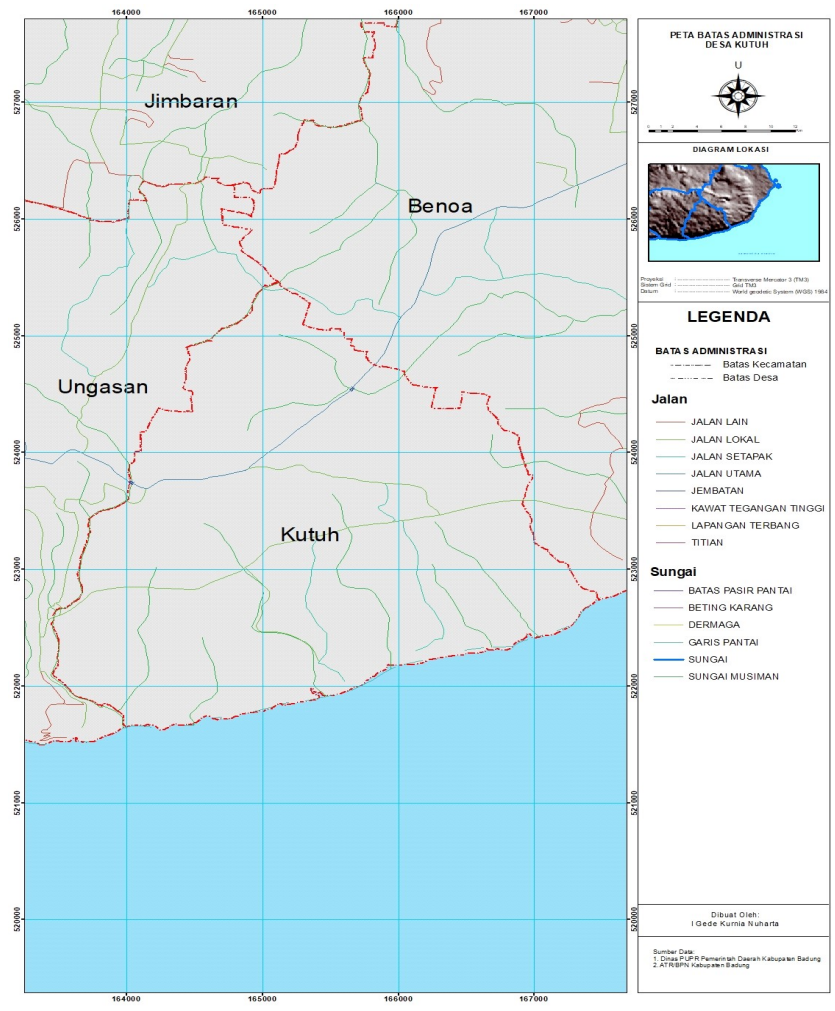

Gambar 2.1. Peta Wilayah Administrasi Desa Kutuh

\subsection{Metodologi}

Penelitian ini menggunakan metode kuantitatif dengan pendekatan spasial. Teknik analisis data yang dilakukan pada penelitiaan ini yaitu analisis spasial menggunakan Sistem Informasi Geografis (SIG) dengan perangkat lunak Arcgis 10.3 dan analisis statistik deskriptif menggunakan Microsoft Excel. Tahapan pelaksanaan penelitian ini disajikan dalam bentuk diagram alir pada Gambar 2.2. Analisis spasial yang dilakukan pada penelitian ini meliputi:

1. Analisis spasial rencana pola ruang Desa Kutuh, menggunakan analisis tools, Extract Clip Peta Rencana Pola Ruang RDTR Kecamatan Kuta Selatan terhadap Peta batas administrasi Desa Kutuh.

2. Analisis spasial nilai tanah zonasi kawasan Desa Kutuh tahun 2012 s.d. 2018, menggunakan Analisis tool, Overlay Spatial Join Peta ZNT Kabupaten Badung tahun 2012 - 2018 terhadap Peta Rencana Pola Ruang Desa Kutuh.

Berdasarkan hasil analisis spasial diatas, dari data attribute table-nya, selanjutnya dilakukan analisis statistik 
untuk mengukur perubahan nilai tanah zonasi kawasan berdasarkan Rencana Pola Ruang RDTR Desa Kutuh. Analisis statistik deskriptif yang dilakukan yaitu:

1. Rata-rata hitung (aritmatik) yaitu penghitungan seluruh nilai data suatu kelompok dibagi dengan jumlah data (anonim, 2013). Rumus rata-rata sebagai berikut:

$$
\bar{x}=\frac{1}{\eta} \sum_{i=1}^{n} \mathrm{xi}
$$

Pada penelitian ini yang dimaksud dengan:

$\bar{x}=$ Nilai tanah rata rata zonasi kawasan $x i=$ Nilai tanah zonasi kawasan ke-i

$\eta=$ Jumlah zonasi kawasan

Hitung prosentase perubahan rata-rata nilai zonasi kawasan setiap tahunnya menggunakan percent rate (Parker, 2002; Adiyaksa \& Nugroho, 2020). Perhitungan tersebut dapat menggunakan persamaan (2).

$$
P R=\frac{v b-v a}{t b-t a} \times 100
$$

Keterangan:

PR: Percent rate

Va : Nilai awal

Vb : Nilai akhir

ta : Waktu pada nilai awal

tb : Waktu pada nilai akhir

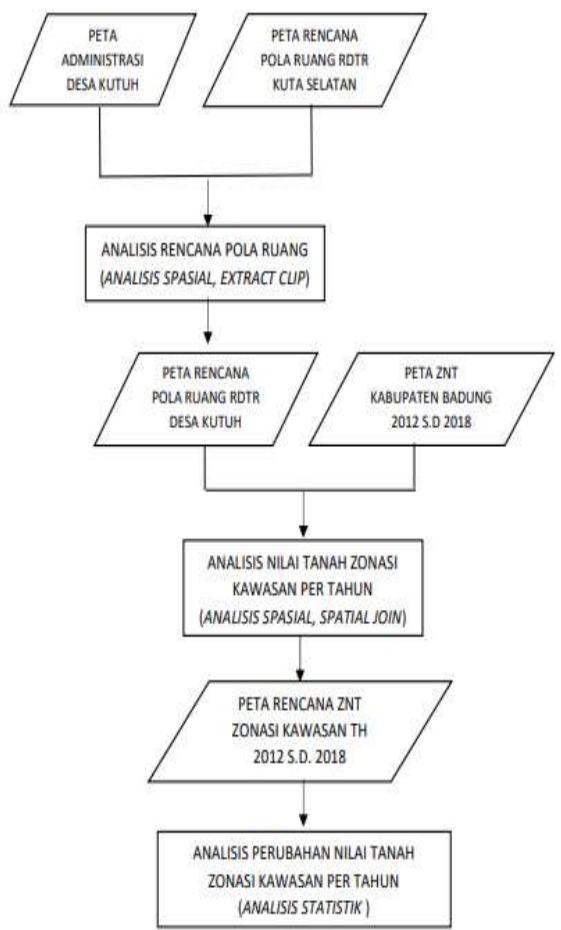

Gambar 2.2. Diagram Alir Penelitian

\section{Hasil dan Pembahasan}

\subsection{Analisis Rencana Pola Ruang Desa Kutuh}

Desa Kutuh berdasarkan RDTR Kecamatan Kuta Selatan masuk dalam Bagian Wilayah Perkotaan (BWP), yang terletak di SUB BWP C, Blok 3 seperti ditunjukkan pada Gambar 3.1.
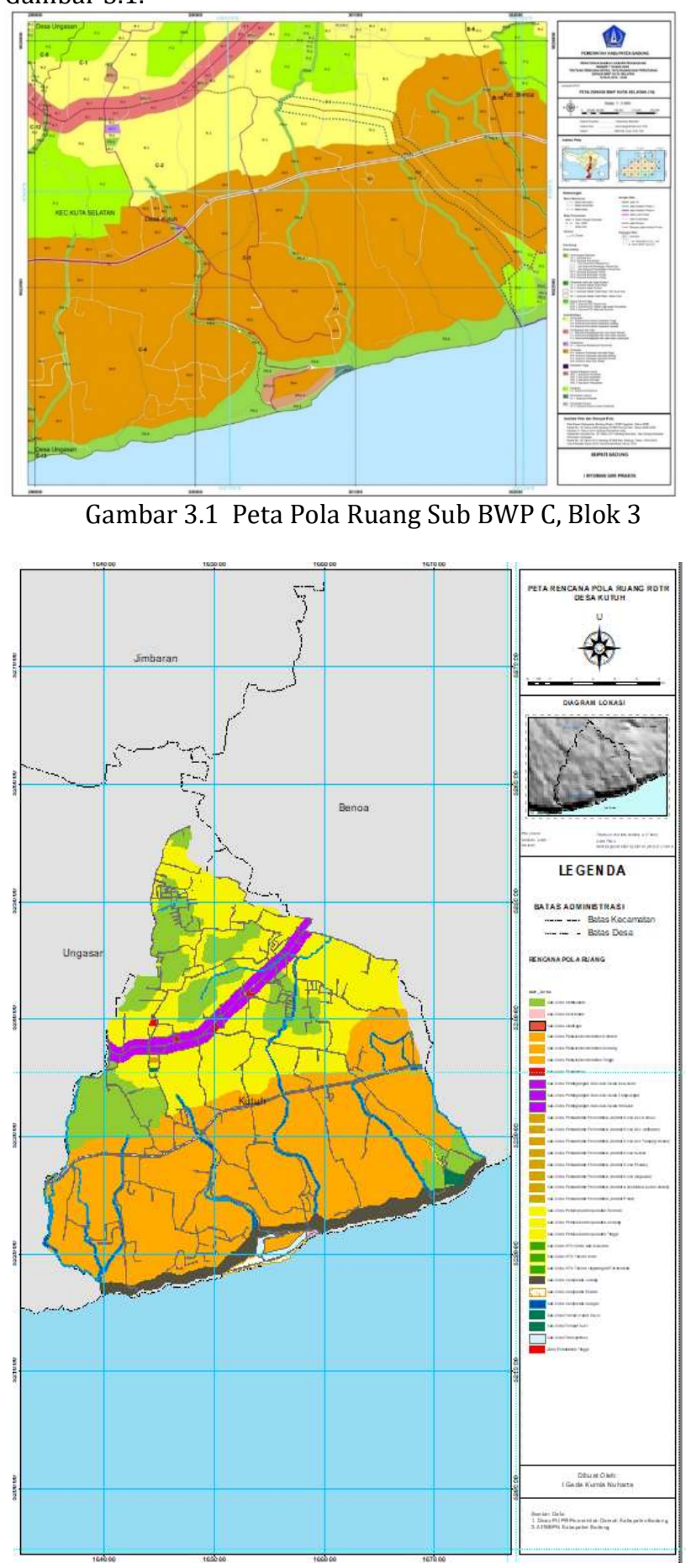

Gambar 3.2 Peta Pola Ruang Desa Kutuh 
Berdasarkan hasil analisis Peta Pola Ruang Desa Kutuh pada gambar 3.2, diperoleh jenis dan luas zonasi kawasan di Desa Kutuh yang ditunjukkan pada Tabel 3.1.

Tabel 3.1 Jenis dan luas zonasi kawasan Desa Kutuh

\begin{tabular}{lrr}
\hline \multicolumn{1}{c}{ Pola Ruang } & Luas HA & Presentase \\
\hline Zona Pariwisata & 423,660 & 47,96 \\
\hline Zona Perdagangan dan Jasa & 28,769 & 3,26 \\
\hline Zona Perkantoran & 0,580 & 0,07 \\
\hline Zona Perlindungan Setempat & 66,238 & 7,50 \\
\hline Zona Pertanian & 130,565 & 14,78 \\
\hline Zona Perumahan & 227,731 & 25,78 \\
\hline Zona Peruntukan Lainnya & 0,551 & 0,06 \\
\hline Zona Ruang Terbuka Hijau & & \\
(RTH) & 0,135 & 0,02 \\
\hline Zona Sarana Pelayanan Umum & 5,181 & 0,59 \\
\hline Total & 883,409 & 100 \\
\hline
\end{tabular}

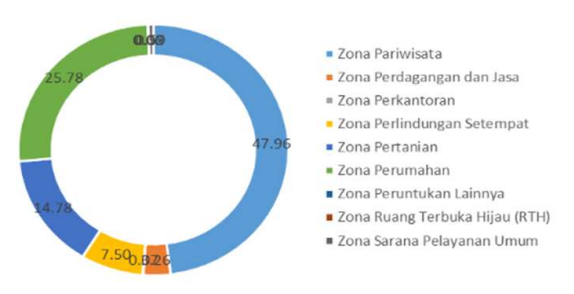

Gambar 3.3 Grafik Rencana Pola Ruang Desa Kutuh

Dari tabel 3.1 dan Gambar 3.3 didapatkan bahwa perencanaan pola ruang Desa Kutuh untuk Zona Budidaya (Zona Pariwisata, Zona Perdagangan dan Jasa, Zona Perkantoran, Zona Perumahan, Zona Peruntukan Lainnya dan Zona Sarana Pelayanan Umum) sebesar $77.71 \%$, sedangkan Zona Lindung (Zona Perlindungan Setempat, Zona Pertanian dan Zona RTH) sebesar $22.29 \%$. Peruntukan Zonasi kawasan paling besar dipergunakan untuk zona pariwisata sebesar $47.96 \%$, sedangkan yang paling rendah adalah Zona Ruang Terbuka Hijau (RTH) sebesar $0.02 \%$.

3.2. Analisis Perubahan Nilai Tanah Zonasi Kawasan Desa Kutuh

Analisis perubahan nilai tanah hanya dilaksanakan pada zona pariwisata, zona perdagangan dan jasa, zona pertanian, zona perumahan, zona peruntukan lainnya dan zona sarana pelayanan umum, sedangkan untuk zona RTH dan zona perlidungan setempat tidak di analisis dengan pertimbangan zona-zona tersebut tidak layak diperjual belikan. Hasil analisis spasial timpang susun (overlay) peta Rencana Pola ruang Desa Kutuh dengan Peta ZNT pertahun sejak tahun 2012 sampai 2018 diperoleh nilai tanah ratarata zonasi kawasan masing - masing tahun.

Berdasarkan nilai tanah rata-rata zonasi kawasan tahun 2012 yang ditampilkan pada Tabel 3.2 dan Gambar 3.4, diperoleh bahwa zonasi perumahan memiliki nilai tanah tertinggi sedangkan zonasi perkantoran memiliki nilai tanah terendah.

Tabel 3.2 Nilai tanah rata-rata zonasi kawasan Tahun 2012

\begin{tabular}{|c|c|}
\hline Pola Ruang & $\begin{array}{c}\text { ZNT_RATA-RATA } \\
\left.\text { (Rupiah } / \mathbf{m}^{2}\right)\end{array}$ \\
\hline Zona Pariwisata & 2.990 .154 \\
\hline Zona Perdagangan dan Jasa & 2.985 .357 \\
\hline Zona Perkantoran & 2.806 .000 \\
\hline Zona Pertanian & 3.073 .692 \\
\hline Zona Perumahan & 3.098 .930 \\
\hline Zona Peruntukan Lainnya & 2.806 .000 \\
\hline Zona Sarana Pelayanan Umum & 2.891 .800 \\
\hline
\end{tabular}

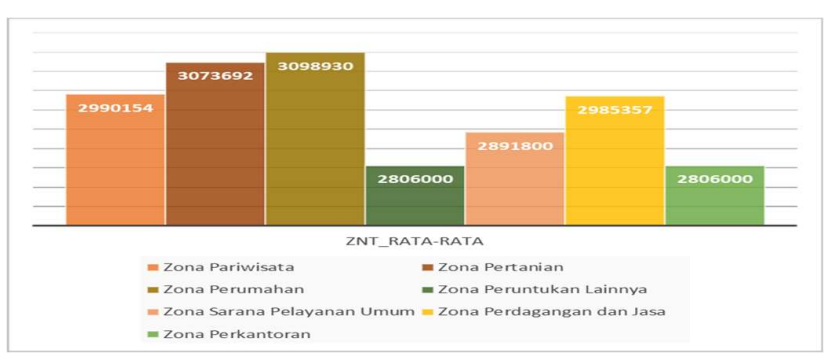

Gambar 3.4 Grafik Nilai Tanah Zonasi Kawasan Th. 2012

Tabel 3.3 Nilai tanah rata-rata zonasi kawasan Tahun 2013

\begin{tabular}{|c|c|}
\hline Pola Ruang & $\begin{array}{l}\text { ZNT_RATA-RATA } \\
\text { (Rupiah/m²) }\end{array}$ \\
\hline Zona Pariwisata & 3.394 .365 \\
\hline Zona Perdagangan dan Jasa & 4.237 .750 \\
\hline Zona Perkantoran & 3.187 .000 \\
\hline Zona Pertanian & 3.447 .135 \\
\hline Zona Perumahan & 3.469 .351 \\
\hline Zona Peruntukan Lainnya & 3.187 .000 \\
\hline Zona Sarana Pelayanan Umum & 4.099 .800 \\
\hline
\end{tabular}

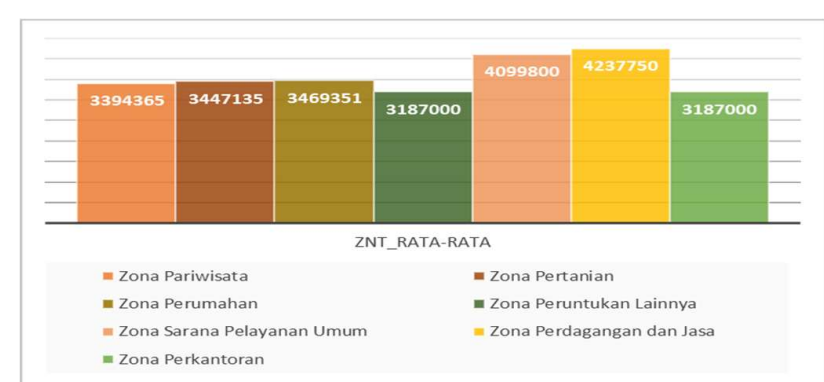

Gambar 3.5 Grafik Nilai Tanah Zonasi Kawasan Th. 2013 
Berdasarkan nilai tanah rata-rata zonasi kawasan tahun 2013 yang ditampilkan pada Tabel 3.3 dan Gambar 3.5, diperoleh bahwa zonasi perdagangan dan jasa memiliki nilai tanah tertinggi sedangkan zonasi perkantoran dan zona peruntukan lainya memiliki nilai tanah terendah.

Tabel 3.4 Nilai tanah rata-rata zonasi kawasan Tahun 2014

\begin{tabular}{|c|c|}
\hline Pola Ruang & $\begin{array}{c}\text { ZNT_RATA-RATA } \\
\left.\text { (Rupiah } / \mathrm{m}^{2}\right)\end{array}$ \\
\hline Zona Pariwisata & 3.729 .846 \\
\hline Zona Perdagangan dan Jasa & 4.898 .179 \\
\hline Zona Perkantoran & 3.500 .000 \\
\hline Zona Pertanian & 3.818 .212 \\
\hline Zona Perumahan & 3.838 .754 \\
\hline Zona Peruntukan Lainnya & 3.500 .000 \\
\hline Zona Sarana Pelayanan Umum & 3.821 .600 \\
\hline
\end{tabular}

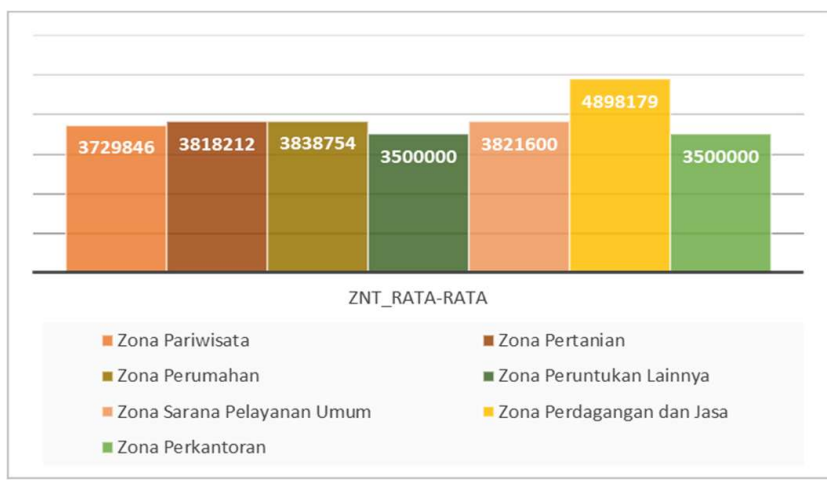

Gambar 3.6 Grafik Nilai Tanah Zonasi Kawasan Th. 2014

Berdasarkan nilai tanah rata-rata zonasi kawasan tahun 2014 yang ditampilkan pada Tabel 3.4 dan Gambar 3.6, diperoleh bahwa zonasi perdagangan dan jasa memiliki nilai tanah tertinggi sedangkan zonasi perkantoran dan zona peruntukan lainnya memiliki nilai tanah terendah.

Tabel 3.5 Nilai tanah rata-rata zonasi kawasan Tahun 2015

\begin{tabular}{|c|c|}
\hline \multicolumn{2}{|c|}{ 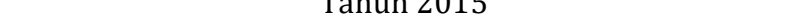 } \\
\hline Pola Ruang & $\begin{array}{l}\text { ZNT_RATA-RATA } \\
\text { (Rupiah/m²) }\end{array}$ \\
\hline Zona Pariwisata & 4.393 .173 \\
\hline Zona Perdagangan dan Jasa & 5.770 .179 \\
\hline Zona Perkantoran & 4.122 .000 \\
\hline Zona Pertanian & 4.497 .481 \\
\hline Zona Perumahan & 4.497 .088 \\
\hline Zona Peruntukan Lainnya & 4.122 .000 \\
\hline Zona Sarana Pelayanan Umum & 5.395 .800 \\
\hline
\end{tabular}

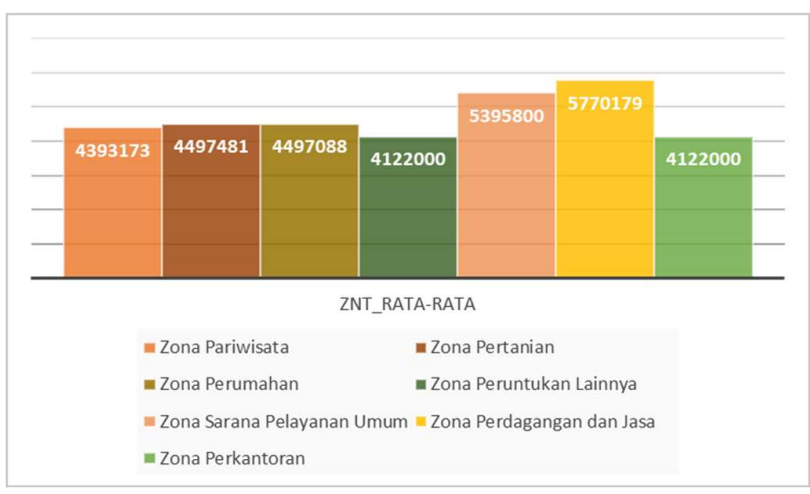

Gambar 3.7 Grafik Nilai Tanah Zonasi Kawasan Th. 2015

Berdasarkan nilai tanah rata-rata zonasi kawasan tahun 2015 yang ditampilkan pada Tabel 3.5 dan Gambar 3.7, diperoleh bahwa zonasi perdagangan dan jasa memiliki nilai tanah tertinggi sedangkan zonasi perkantoran dan zona peruntukan lainnya memiliki nilai tanah terendah.

Tabel 3.6 Nilai tanah rata-rata zonasi kawasan Tahun 2016

\begin{tabular}{lr}
\hline \multicolumn{1}{c}{ Pola Ruang } & $\begin{array}{r}\text { ZNT_RATA-RATA } \\
\text { (Rupiah/m²) }\end{array}$ \\
\hline Zona Pariwisata & 4.468 .558 \\
\hline Zona Perdagangan dan Jasa & 5.868 .857 \\
\hline Zona Perkantoran & 4.193 .000 \\
\hline Zona Pertanian & 4.574 .808 \\
\hline Zona Perumahan & 4.574 .263 \\
\hline Zona Peruntukan Lainnya & 4.193 .000 \\
\hline Zona Sarana Pelayanan Umum & 5.488 .200 \\
\hline
\end{tabular}

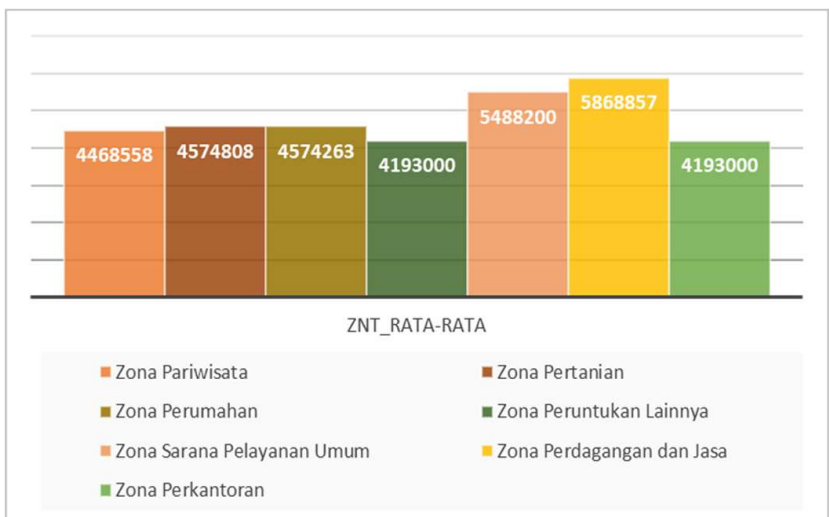

Gambar 3.8 Grafik Nilai Tanah Zonasi Kawasan Th. 2016

Berdasarkan nilai tanah rata-rata zonasi kawasan tahun 2016 yang ditampilkan pada Tabel 3.6 dan Gambar 3.8, diperoleh bahwa zonasi perdagangan dan jasa memiliki nilai tanah tertinggi sedangkan zonasi perkantoran dan zona peruntukan lainnya memiliki nilai tanah terendah. 
Tabel 3.7 Nilai tanah rata-rata zonasi kawasan Tahun 2017

\begin{tabular}{lc}
\hline \multicolumn{1}{c}{ Pola Ruang } & $\begin{array}{c}\text { ZNT_RATA-RATA } \\
\text { (Rupiah/m } \mathbf{m}^{\mathbf{2}}\end{array}$ \\
\hline Zona Pariwisata & 4.449 .596 \\
\hline Zona Perdagangan dan Jasa & 5.098 .393 \\
\hline Zona Perkantoran & 4.200 .000 \\
\hline Zona Pertanian & 4.013 .115 \\
\hline Zona Perumahan & 3.900 .123 \\
\hline Zona Peruntukan Lainnya & 3.639 .000 \\
\hline Zona Sarana Pelayanan & 4.763 .000 \\
Umum & \\
\hline
\end{tabular}

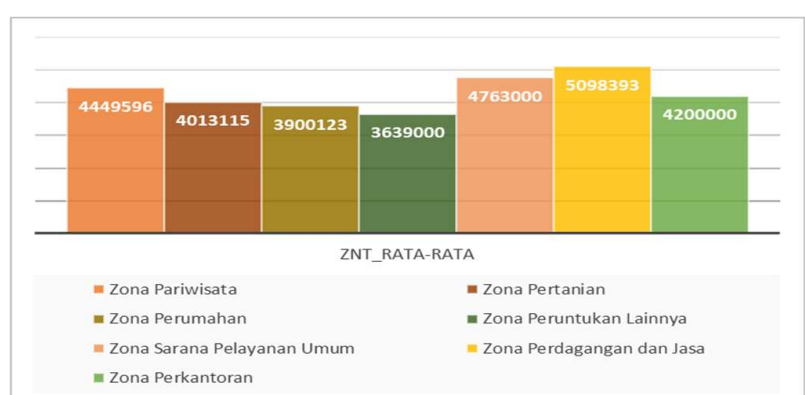

Gambar 3.9 Grafik Nilai Tanah Zonasi Kawasan Th. 2017

Berdasarkan nilai tanah rata-rata zonasi kawasan tahun 2017 yang ditampilkan pada Tabel 3.7 dan Gambar 3.9, diperoleh bahwa zonasi perdagangan dan jasa memiliki nilai tanah tertinggi sedangkan zonasi peruntukan lainnya memiliki nilai tanah terendah.

Tabel 3.8 Nilai tanah rata-rata zonasi kawasan Tahun 2018

\begin{tabular}{lc}
\hline \multicolumn{1}{c}{ Pola Ruang } & $\begin{array}{c}\text { ZNT_RATA-RATA } \\
\text { (Rupiah/m2) }\end{array}$ \\
\hline Zona Pariwisata & 4.449 .596 \\
\hline Zona Perdagangan dan Jasa & 5.098 .393 \\
\hline Zona Perkantoran & 4.200 .000 \\
\hline Zona Pertanian & 4.013 .115 \\
\hline Zona Perumahan & 3.900 .123 \\
\hline Zona Peruntukan Lainnya & 3.639 .000 \\
\hline Zona Sarana Pelayanan Umum & 4.763 .000 \\
\hline
\end{tabular}

Untuk nilai tanah rata-rata zonasi kawasan tahun 2018 sesuai dengan tabel 3.8 tidak terdapat perubahan nilai tanah dengan tahun 2017, sehingga zonasi perdagangan dan jasa memiliki nilai tanah tertinggi sedangkan zonasi peruntukan lainnya memiliki nilai tanah terendah.

Nilai tanah rata-rata zonasi kawasan dari tahun 2012 sampai dengan tahun 2018 dapat dilihat pada tabel 3.9. Berdasarkan hasil perhitungan nilai tanah rata-rata zonasi pada tabel 3.9, selanjutnya dihitung perubahan nilai masing-masing zonasi kawasan yang disajikan pada tabel 3.10 .

Tabel 3.9 Nilai tanah rata-rata zonasi kawasan pertahun $2012-2018$

\begin{tabular}{|l|c|c|c|c|c|c|c|}
\hline \multirow{3}{*}{ ZoNA } & \multicolumn{7}{|c|}{ NILAl TANAHRATA-RATA (Rupiah/m2) } \\
\cline { 2 - 8 } & 2012 & 2013 & 2014 & 2015 & 2016 & 2017 & 2018 \\
\hline Zona Pariwisata & 2.990 .154 & 3.394 .365 & 3.729 .846 & 4.393 .173 & 4.468 .558 & 4.449 .596 & 4.449 .596 \\
\hline Zona Perdagangan dan Jasa & 2.985 .357 & 4.237 .750 & 4.898 .179 & 5.770 .179 & 5.868 .857 & 5.098 .393 & 5.098 .393 \\
\hline Zona Perkantoran & 2.806 .000 & 3.187 .000 & 3.500 .000 & 4.122 .000 & 4.193 .000 & 4.200 .000 & 4.200 .000 \\
\hline Zona Pertanian & 3.073 .692 & 3.447 .135 & 3.818 .212 & 4.497 .481 & 4.574 .808 & 4.013 .115 & 4.013 .115 \\
\hline Zona Perumahan & 3.098 .930 & 3.469 .351 & 3.838 .754 & 4.497 .088 & 4.574 .263 & 3.900 .123 & 3.900 .123 \\
\hline Zona Peruntukan Lainnya & 2.806 .000 & 3.187 .000 & 3.500 .000 & 4.122 .000 & 4.193 .000 & 3.639 .000 & 3.639 .000 \\
\hline Zona Sarana Pelayanan Umum & 2.891 .800 & 4.099 .800 & 3.821 .600 & 5.395 .800 & 5.488 .200 & 4.763 .000 & 4.763 .000 \\
\hline
\end{tabular}

Tabel 3.10 Perubahan nilai tanah rata-rata zonasi kawasan pertahun

\begin{tabular}{|l|r|r|r|r|r|r|}
\hline \multirow{2}{*}{ ZONA } & \multicolumn{6}{|c|}{ PERUBAHAN NILAI TANAH RATA-RATA (Rupiah/ $\left.\mathrm{m}^{2}\right)$} \\
\cline { 2 - 8 } & $2012-2013$ & $2013-2014$ & $2014-2015$ & $2015-2016$ & $2016-2017$ & $2017-2018$ \\
\hline Zona Pariwisata & 404.212 & 335.481 & 663.327 & 75.385 & $(18.962)$ & - \\
\hline Zona Perdagangan dan Jasa & 1.252 .393 & 660.429 & 872.000 & 98.679 & $(770.464)$ & - \\
\hline Zona Perkantoran & 381.000 & 313.000 & 622.000 & 71.000 & 7.000 & - \\
\hline Zona Pertanian & 373.442 & 371.077 & 679.269 & 77.327 & $(561.692)$ & - \\
\hline Zona Perumahan & 370.421 & 369.404 & 658.333 & 77.175 & $(674.140)$ & - \\
\hline Zona Peruntukan Lainnya & 381.000 & 313.000 & 622.000 & 71.000 & $(554.000)$ & - \\
\hline Zona Sarana Pelayanan Umum & 1.208 .000 & $(278.200)$ & 1.574 .200 & 92.400 & $(725.200)$ & - \\
\hline
\end{tabular}

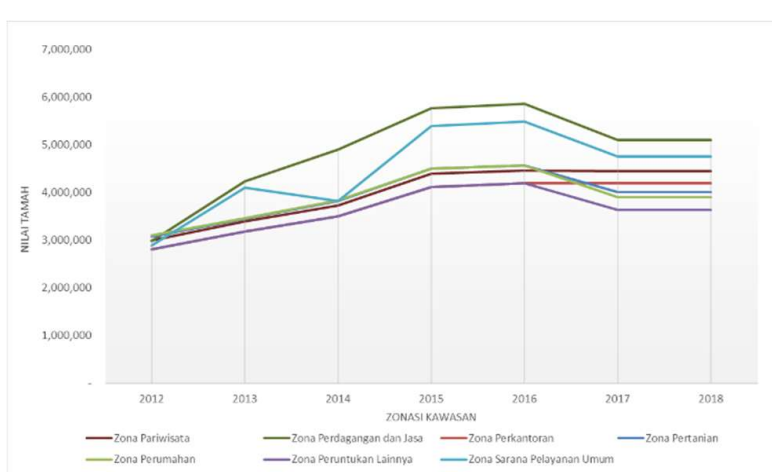

Gambar 3.10 Grafik Nilai Tanah Zonasi Kawasan Th. 20122018

Tabel 3.11 Prosentase perubahan nilai tanah rata-rata zonasi kawasan pertahun

\begin{tabular}{|c|c|c|c|c|c|c|c|c|}
\hline \multirow{3}{*}{ ZONA } & \multicolumn{8}{|c|}{ TAHUN } \\
\hline & 2012-2013 & 2013-201 & 2014-2015 & 2015-2016 & 2016-2017 & $2017-2018$ & TOTAL & \begin{tabular}{|l} 
RATA-RATA \\
PERUBAHA \\
$\mathrm{N} 2012-2018$ \\
\end{tabular} \\
\hline & $\%$ & $\%$ & $\%$ & $\%$ & $\%$ & $\%$ & $\%$ & $\%$ \\
\hline Zona Pariwisata & 13.52 & 9.88 & 17.78 & 1.72 & -0.42 & 0.00 & 42 & 7.08 \\
\hline Zona Perdagangan dan Jasa & 41.95 & 15.58 & 17.80 & 1.71 & -13.13 & 0.00 & 64 & 10.65 \\
\hline Zona Perkantoran & 13.58 & 9.82 & 17.77 & 1.72 & 0.17 & 0.00 & 43 & 7.18 \\
\hline Zona Pertanian & 12.15 & 10.76 & 17.79 & 1.72 & -12.28 & 0.00 & 30 & 5.02 \\
\hline Zona Perumahan & 11.95 & 10.65 & 17.15 & 1.72 & -14.74 & 0.00 & 27 & 4.45 \\
\hline Zona Peruntukan Lainnya & 13.58 & 9.82 & 17.77 & 1.72 & -13.21 & 0.00 & 30 & 4.95 \\
\hline Zona Sarana Pelayanan Umum & 41.77 & -6.79 & 41.19 & 1.71 & -13.21 & 0.00 & 65 & 10.78 \\
\hline PERSENTASE PERUBAHAN & & & & & & & & \\
\hline $\begin{array}{l}\text { NILAI TANAH RATA-RATA } \\
\text { PERTAHUN }\end{array}$ & 21.21 & 8.53 & 21.04 & 1.72 & -9.55 & 0.00 & 42.96 & 7.16 \\
\hline
\end{tabular}


Berdasarkan data perubahan nilai tanah rata-rata zonasi kawasan pada tabel 3.9, tabel 3.10 dan tabel 3.11, dapat disampaikan hasil analisis perubahan nilai tanah rata-rata zonasi kawasan, sebagai berikut:

1. Nilai tanah rata-rata zonasi kawasan di Desa Kutuh (tabel 3.9), sejak tahun 2012 sampai dengan 2017 mengalami perubahan nilai tanah sedangkan pada tahun 2018 tidak terdapat perubahan dengan tahun 2017.

2. Nilai tanah rata-rata zonasi kawasan di Desa Kutuh (tabel 3.10) mengalami peningkatan pada tahun 2012 sampai dengan tahun 2016, sedangkan mengalami penurunan pada tahun 2017 kecuali pada zonasi perkantoran.

3. Peningkatan Nilai tanah rata-rata zonasi kawasan di Desa Kutuh (tabel 3.11) tertinggi terjadi pada tahun 2013 yaitu $21.21 \%$, sedangkan terendah terjadi pada tahun 2016 sebesar $1.72 \%$.

4. Prosentase rata-rata peningkatan nilai tanah tahun 2012 sampai dengan tahun 2018 (tabel 3.11) tertinggi pada zona sarana pelayanan umum sebesar $10,78 \%$ dan prosentase rata-rata peningkatan nilai tanah terendah pada zona perumahan sebesar $4,45 \%$.

\section{Kesimpulan}

Dari penelitian ini dapat ditarik beberapa kesimpulan berdasarkan hasil analisis Pola Ruang Rencana Detil Tata Ruang (RDTR) Kecamatan Kuta Selatan, pemerintah Kabupaten Badung telah merencanakan pengembangan kawasan pariwisata di Desa Kutuh seiring dengan berkembangnya obyek daya tarik pariwisata Pantai Pandawa dengan rencana pengembangan zona budidaya penunjang pariwisata sebesar $77.71 \%$. Dari hasil analisis perubahan nilai tanah rata-rata zonasi kawasan didapatkan bahwa pada tahun 2012 sampai dengan tahun 2016 mengalami peningkatan tiap tahunnya sejalan dengan perkembangan pariwisata di Pantai Pandawa hal ini dibuktikan dengan terjadinya peningkatan nilai tanah serta nilai rata-rata zonasi kawasan dari tahun 2012-2018 pada zonasi pelayanan umum yang berada dikawasan obyek daya tarik obyek wisata Pantai Pandawa memiliki peningkatan nilai tanah zonasi rata-rata kawasan tertinggi sebesar $10.78 \%$, sedangkan pada tahun 2017 mengalami penurunan nilai tanah yang belum dapat diidentifikasi pada penelitian ini faktor-faktor yang mempengaruhi kondisi tersebut, oleh karena itu perlu dilakukan penelitian lebih lanjut.

\section{Pernyataan Konflik Kepentingan}

Penulis menyatakan tidak ada konflik kepentingan dalam artikel ini (The authors declare no competing interest).

\section{Referensi}

Adiyaksa, F. \& Nugroho, P. D. (2020). Evaluasi Alih Fungsi Lahan Pertanian Menjadi Lahan Industri di Kabupaten Kendal Tahun 2014 - 2018. JGISE: Journal of Geospatial Information Science and Engineering Vol. 3, No.1, (2020),

https://doi.org/10.22146/igise.55519

pp.71-78.

Aditya, T., Maria-Unger, E., Berg, C., Bennett, R., Saers, P., Syahid, H. L., Erwan, D., Wits, T., Widjajanti, N., Santosa, P. B., Atunggal, D., Hanafi, I., dan Sutejo, D. (2020). Participatory Land Administration in Indonesia: Quality and Usability Assessment.Land. 9(3), 79. https://doi.org/10.3390/land9030079

Al-Vatia, T. V., \& Nugroho, P. D. (2019). Analysis of the Effect of Land Use Planning and Land Value in Gamping Subdistrict, Sleman, D.I Yogyakarta from 2013 to 2018. JGISE: Journal of Geospatial Information Science and Engineering. Vol. 2 No. 2, pp. 245 - 254. https://jurnal.ugm.ac.id/igise/article/view/51076

Anonim.(2013).https://www.rumusstatistik.com/2013/0 7/rata-rata-mean-atau-rataan.html, Diakses pada 23 Juni 2020

Anugrah, R, Subiyanto, S. \& Hani'ah. (2017). Analisis Perubahan Nilai Tanah Akibat Perubahan Penggunaan Tanah Menggunakan SIG di Pulau Karimunjawa Dan Pulau Kemojan Tahun 2010 Dan 2016. Jurnal Geodesi Undip., Volume 6, Nomor 4, 2017. https://ejournal3.undip.ac.id/index.php/geodesi/arti cle/view/18135

Aristalindra, F., Santosa, P. B., Diyono \& Subaryono (2020). Evaluasi Pemanfaatan Citra Tegak Satelit Resolusi Tinggi untuk Percepatan Pembuatan Peta Blok Pajak Bumi dan Bangunan (PBB-P2) secara Partisipatif di Desa Triharjo, Kabupaten Bantul, DIY.JGISE: Journal of Geospatial Information Science and Engineering. Vol. 3 No. 1. https://doi.org/10.22146/igise.55788

Astrisele, A. \& Santosa, P. B. (2019). Estimating Land Value Change Post Land Consolidation of Gadingsari Village, Bantul Regency, Special Region of Yogyakarta, Indonesia. JGISE: Journal of Geospatial Information Science and Engineering. Vol. 2 No. 2. https://doi.org/10.22146/igise.51309

Astuti, A., Subiyanto, S. \& Hani'ah (2015). Analisis Pengaruh Perubahan Nilai Jual Tanah Terhadap Zona Nilai Tanah. Jurnal Geodesi Undip Volume4,Nomor1.https://ejournal3.undip.ac.id/index .php/geodesi/article/view/7640

Bambar, A. F. \& Anom, I. P. (2016). Partisipasi Masyarakat Dalam Pengembangan Pariwisata Di Pantai Pandawa, Desa Kutuh, Kuta Selatan, Badung. Jurnal Destinasi Pariwisata. Vol. $\quad 4 \quad$ No 2.https://ojs.unud.ac.id/index.php/destinasipar/arti cle/view/25325

Dipayana, A., \& Sunarta, I. N. (2015). Dampak Pariwisata Terhadap Alih Fungsi Lahan di Desa Tibubeneng 
Kecamatan Kuta Utara Kabupaten Badung (studi sosial-budaya). Jurnal Destinasi Pariwisata. Vol.3,No2,2015.https://ojs.unud.ac.id/index.php/dest inasipar/article/view/23246

Oksaping, A. F., Djurdjani, dan Nugroho, P. (2019). Land Valuation with Analytical Hierarchy Process and Regression Method in Grogol Sub-District, Sukoharjo District. JGISE: Journal of Geospatial Information Science and Engineering. Vol. 2 No. 1. https://doi.org/10.22146/igise.40845

Patera, I. M. (2016). Pariwisata dan Kemiskinan di Kabupaten Badung, Bali. Universitas Udayana.

Sihombing, S., Subiyanto, S. \& Amarrohman, F.J. (2018). Analisis Perubahan Nilai Tanah Akibat Perkembangan Fisik Dengan Menggunakan Metode Sistem Informasi Geografis (Studi Kasus: Kecamatan Tembalang). Jurnal Geodesi Undip. https://ejournal3.undip.ac.id/index.php/geodesi/arti cle/viewFile/21211/19800
Sutawijaya, A. (2004). Analisis Faktor-Faktor Yang Mempengaruhi Nilai Tanah Sebagai Dasar Penilaian Nilai Jual Obyek Pajak (NJOP) PBB di Kota Semarang. Jurnal Ekonomi Pembangunan. Vol. 9, No. 1, Hal:65-78. https://journal.uii.ac.id/IEP/article/view/625

Tampubolon, J. I., Amalia, K. \& Nirfalini, A. D. (2016). Analisis Perubahan Nilai Tanah Akibat Perpindahan Bandara Polonia Di Kelurahan Anggrung Kecamatan Medan Polonia Kota Medan. Jurnal Ekonom, Vol 19, No 2 http://repository.usu.ac.id/handle/123456789/645 $\underline{02}$

Widiarsa, I. P. A. \& Suartika, G. A. M. (2018). Pengendalian Alih Fungsi Lahan Pertanian Di Kawasan Perkotaan Mangupura Kabupaten Badung. Jurnal Ruang/Space. Volume 5, no. 2, Oktober 2018. https://ojs.unud.ac.id/index.php/ruang/article/view $\lcm{42995}$ 